Western North American Naturalist 67(4), (C) 2007, pp. 469-491

\title{
VARIATION IN ANT POPULATIONS WITH ELEVATION, TREE COVER, AND FIRE IN A PINYON-JUNIPER-DOMINATED WATERSHED
}

\author{
Eugénie M. MontBlanc ${ }^{1,2}$, Jeanne C. Chambers ${ }^{3}$, and Peter F. Brussard ${ }^{1}$
}

\begin{abstract}
Climate change and fire suppression have facilitated expansion of pinyon-juniper woodlands into sagebrush-steppe ecosystems of the Great Basin, USA, resulting in a loss of biological diversity. To assess the effects of using prescribed fire in restoration efforts, ant abundance, species richness, and composition were examined pre- and post-burn along the elevation and tree cover gradients encompassed by a pinyon-juniper woodland in a central Nevada watershed. Ants were sampled using pitfall traps in 6 sites for the elevation study and in 2 sites for the tree cover study, representing paired burn and control sites in a randomized block design. Vegetation and ground cover variables were also sampled to determine how variation in ant populations was correlated with differences in vegetation and ground cover. Ant species richness remained unchanged for all treatments. Tree cover had no significant effect on ant populations. Significantly more ants were trapped after the burn treatment on burn plots. Variation in ant populations was not directly correlated with any of the vegetation or ground cover variables. According to ANOVA and multivariate analyses, elevation had the greatest effect on changes in ant communities, likely due to increased moisture availability. Our results suggest that management for conservation of sagebrush-steppe ecosystems in this and similar watersheds should include a range of elevations to ensure maximum ant species diversity.
\end{abstract}

Key words: ants, prescribed fire, elevation gradients, tree cover, Great Basin, pinyon-juniper woodland, sagebrush steppe, ecosystem management, restoration.

Climate change, overgrazing by livestock, and fire suppression have facilitated expansion of pinyon (Pinus monophylla) and juniper (Juniperus osteosperma) woodlands into sagebrush ecosystems of the Great Basin (Tausch et al. 1981, Miller and Rose 1999, Miller and Tausch 2001, Tausch et al. 2004). The tree expansion has occurred over an elevation gradient that includes several sagebrush community types: Wyoming sagebrush (Artemisia tridentata wyomingensis) at the lowest elevations, Vasey sagebrush (Artemisia tridentata vaseyana) at intermediate elevations, and mountain brush communities with Vasey sagebrush at the highest elevations (Chambers et al. 2000). Increases in tree stand densities over time result in the reduction of both sagebrush and perennial herbaceous vegetation (Tausch and Tueller 1990, Miller et al. 2000). A reduction in fine herbaceous vegetation and an increase in dense woody vegetation have resulted in a decrease in more-frequent, low-impact fires and an increase in less-frequent, more-severe crown fires (Swetnam 1993, Miller and Rose 1999, Kauffman 2004). A decrease in perennial herbaceous vegetation coupled with the altered fire regimes has facilitated the invasion of the fire-adapted annual grass cheatgrass (Bromus tectorum) into these ecosystems (Chambers et al. 2000, Miller et al. 2000). These changes have placed sagebrush ecosystems and their associated animal taxa at risk of decline or extirpation (Wisdom et al. 2002).

Management of these ecosystems is increasingly focused on prescribed fire or fire surrogate treatments like mechanical removal. These types of fire treatments are used to manipulate wildlife habitat by reducing the incidence of severe wildfires and stimulating regeneration of certain plant species (Andrew et al. 2000, York 2000). To effectively use fire treatments to manage the expansion of pinyon-juniper woodlands, we must first gain an understanding of how patterns of diversity and abundance in animal communities change over environmental gradients and with increases in tree densities. Then we must examine how prescribed fire influences these patterns.

Ecologists are paying increasing attention to ants as bioindicators in restoration and landuse management (Andersen and Sparling 1997, Andersen and Müller 2000, Andrew et al. 2000,

\footnotetext{
${ }^{1}$ University of Nevada, Department of Biology, MS 314, Reno, NV 89557.

2 Present address: USDA Forest Service, Rocky Mountain Research Station, 920 Valley Road, Reno, NV 89512. E-mail: geniemb@unr.edu

${ }^{3}$ USDA Forest Service, Rocky Mountain Research Station, 920 Valley Road, Reno, NV 89512.
} 
Golden and Crist 2000, Andersen et al. 2003, Andersen and Majer 2004). Ants are abundant, diverse, and ecologically dominant in almost every terrestrial environment around the world (Hölldobler and Wilson 1990, Wilson 2000). They carry out many important ecosystem functions at various trophic levels (Andersen et al. 2002, Sanders et al. 2003, Maeto and Sato 2004) and respond to environmental variation in ecologically interpretable ways (Agosti et al. 2000, Andrew et al. 2000, Read and Andersen 2000, Bestelmeyer and Wiens 2001, Andersen et al. 2002, 2003, Maeto and Sato 2004). These characteristics make ants an appropriate taxon to consider in assessments of restoration and management programs. Previous studies of ant diversity in arid or semiarid environments show that ants respond to soil texture and moisture gradients (Bestelmeyer and Wiens 1996, 2001, Whitford et al. 1999, Sanders et al. 2003) and indicate that ants also should vary with elevation and tree stand density.

Much of the work on ants in the Great Basin has focused on individual species or groups of species with specific functions such as seed harvesting or thatch-mound building (Davidson et al. 1984, 1985, Crist and MacMahon 1991, 1992, Mull and MacMahon 1997, McIver and Yandell 1998). There are few previous studies on changes in ant communities along elevation gradients and in response to fire in the Great Basin, and we are unaware of any previous studies examining ant community response to varying tree densities. We found 2 studies of variation in ant species along elevation gradients in the Great Basin. Sanders (2002) determined that ant species richness was highest at intermediate elevations and attributed that result to study area size and geometric constraints. Also, Sanders et al. (2003) found that species richness was greatest at high elevations and attributed that result to temperature and water availability. In relation to tree cover, 1 study conducted in the Sonoran Desert (Bestelmeyer and Schooley 1999) found that ant species composition, but not richness, was influenced more by tree-shaded microhabitats compared to open ground. Some studies have determined that both age distribution and fragmentation of forests affect ant species composition and richness, with the greatest richness in the early stages of forest succession occurring where there is a greater range of understory vegetation age classes (Punttila et al. 1994, York 1994). In response to fire, ant communities in arid systems in Idaho and New Mexico showed no significant changes (Zimmer and Parmenter 1998, Bliss et al. 1999) except for an increase in abundance (Zimmer and Parmenter 1998). Much of the work shows that ant community composition rather than species richness changes following fire (Andersen and Yen 1985, Andersen 1991, York 2000, Farji-Brener et al. 2002). Nearly all of these studies show that ant abundance increases after fire.

Knowledge of ant community assemblages in sagebrush and pinyon-juniper habitats can improve predictions about the response of this system to fire management treatments. We examined ant abundance, species richness, and community composition along an elevation gradient, within 3 tree densities, and before and after a prescribed fire treatment in 1 canyon in the central Great Basin. We asked 4 related questions. The first 3 questions address variation in ant populations in regard to the 3 main variables of interest, while the 4 th question addresses correlations between variation in ant communities and variation in plant communities: (1) How do ant abundance, species richness, and community composition change in relation to an elevation gradient that typifies pinyon-juniper woodlands in the Great Basin? (2) How do ant abundance, species richness, and community composition change with increases in tree cover? (3) How do ant abundance, species richness, and community composition change in response to prescribed fire? (4) How do changes in ant abundance, species richness, and community composition relate to the vegetation community cover or habitat characteristics that occur over the elevation and tree cover gradients?

\section{METHODS}

\section{Study Area}

The study sites were located along an elevation gradient within Underdown Canyon $\left(39^{\circ} 10^{\prime} \mathrm{N}, 117^{\circ} 25^{\prime} \mathrm{W}\right)$ in the Shoshone Mountain Range, Lander County, Nevada. This area is part of the Humboldt-Toiyabe National Forest (Austin Ranger District) and the BLM Battle Mountain District in central Nevada. The sites were located on north-facing alluvial fans and ranged from $2073 \mathrm{~m}$ to $2347 \mathrm{~m}$ in elevation. 


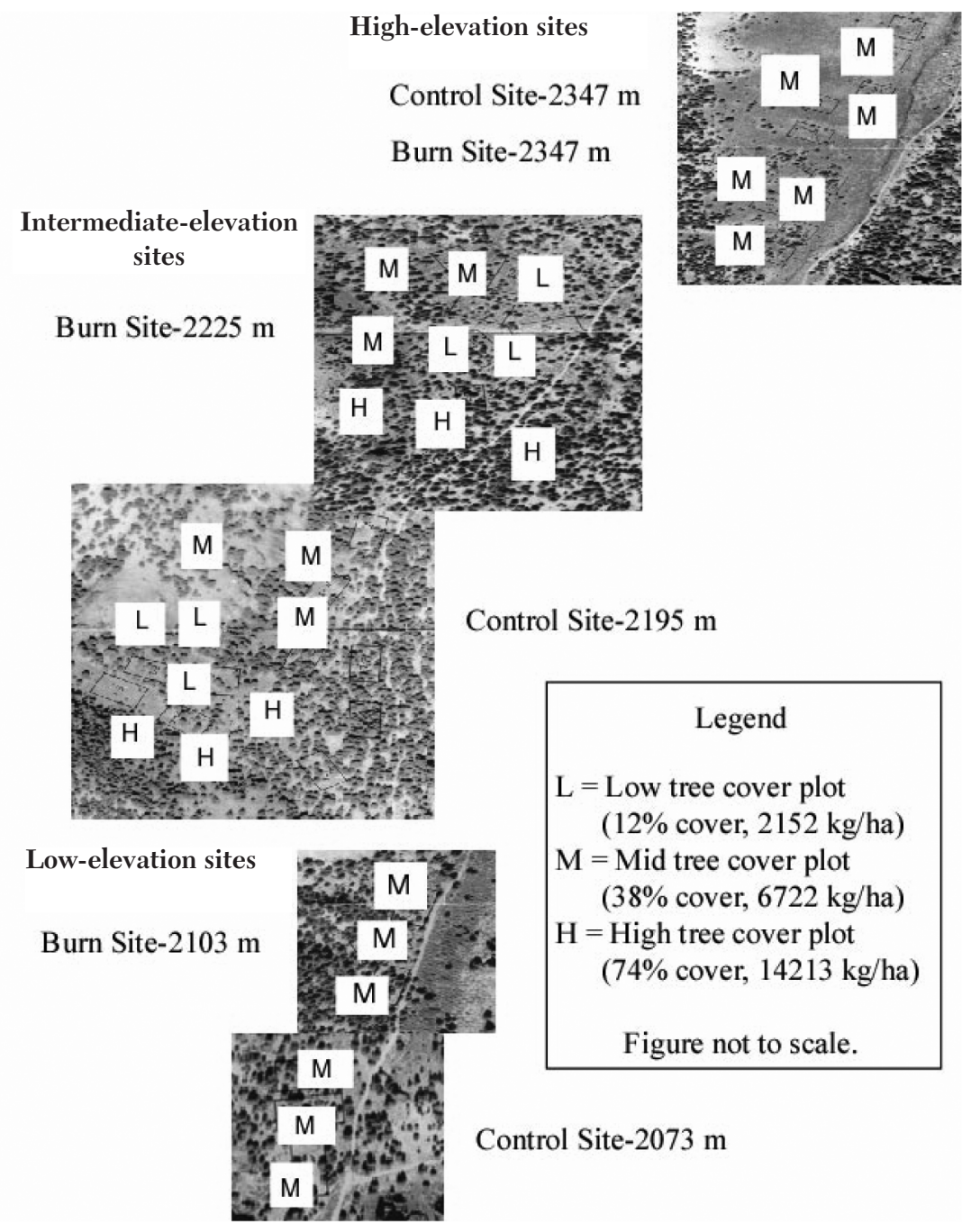

Fig. 1. An illustration of the study design. Only the intermediate tree cover plots were used for the elevation study, and only the intermediate-elevation sites were used for the tree cover study.

Underdown Canyon has the cool desert climate typical of the Great Basin: cold and wet in the winter and hot and dry in the summer. Annual precipitation falls mostly during the winter and spring months, and the yearly average ranges from $23 \mathrm{~cm}$ at lower elevations to $50 \mathrm{~cm}$ at higher elevations (Chambers et al. 2000). Temperatures range from an average of $-7.2^{\circ} \mathrm{C}$ in January to $29.4^{\circ} \mathrm{C}$ in July (Weixelman et al. 1996). The geology of this canyon is characterized by volcanic rock, the soil is classified as Loamy-skeletal Frigid Xeroll derived from welded tuff, and all layers of the soil profile have a sandy loam texture to $100 \mathrm{~cm}$ (Rau et al.
2005). There are 2 springs in the upper reaches of this canyon, and the stream system is ephemeral, only flowing during runoff from spring snowmelt. Livestock grazing was the primary historical land use in this area; however, grazing had not occurred for 7 years prior to this study (Terry Nevius, USDA Forest Service, Austin Ranger District, personal communication).

The pinyon-juniper woodlands are dominated by single-leaf pinyon with lower densities of Utah juniper, western juniper (Juniperus occidentalis), and Utah juniper-western juniper hybrids. Associated sagebrush communities are dominated by Wyoming sagebrush at lower 
elevations and include perennial grasses such as Sandberg's bluegrass (Poa secunda secunda), bottlebrush squirreltail (Elymus elymoides), and needle-and-thread grass (Stipa comata). Higher-elevation sagebrush communities are dominated by mountain big sagebrush and perennial grasses such as Idaho fescue (Festuca idahoensis) and bluebunch wheatgrass (Pseudoruegneria spicata). Forbs in the study area include Eriogonum spp., Crepis acuminata, Phlox longifolia, Agoseris glauca, Lupinus argenteus, and Penstemon spp. (Chambers et al. 2000).

\section{Study Design}

We used 2 randomized block designs to investigate changes in ant communities. First, to determine how ant species richness and individual abundance change over the elevation gradient within the canyon, paired burn and control sites were located at low $(2103 \mathrm{~m}$ and $2073 \mathrm{~m}$ ), intermediate $(2225 \mathrm{~m}$ and 2195 $\mathrm{m})$, and high $(2347 \mathrm{~m})$ elevations $(n=6)$. Three subplots were located within each of the paired burn and control sites. To control for variation in tree cover among these plots, the plots were located in areas characterized by intermediate tree cover. It was not possible to select identical intermediate tree cover values on all sites along the elevation gradient. Therefore, the intermediate tree cover values along the elevation gradient ranged from an average of $48.4 \%$ at the low-elevation sites to $22.9 \%$ at the high-elevation sites. Second, to determine how ant species richness and individual abundance change with differences in tree cover, 3 subplots were located in areas characterized by low (12\% cover, $\left.2152 \mathrm{~kg} \cdot \mathrm{ha}^{-1}\right)$, intermediate $\left(38 \%\right.$ cover, $\left.6722 \mathrm{~kg} \cdot \mathrm{ha}^{-1}\right)$, and high $(74 \%$ cover, $14,213 \mathrm{~kg} \cdot \mathrm{ha}^{-1}$ ) tree cover (Reiner 2004) within the paired burn and control sites at the intermediate elevations $(2103 \mathrm{~m}$ and $2073 \mathrm{~m}$; Fig. 1). Plots varied in shape, but all were 0.1 ha in size. The prescribed burns were conducted on 10-13 May 2002 by HumboldtToiyabe National Forest personnel using standard techniques.

\section{Ant Sampling}

We sampled ants using pitfall traps because most ants in arid and semiarid systems are ground-dwelling and ground-foraging species (Jeff Knight, Nevada Department of Agriculture, Entomology Laboratory, personal communication) and because pitfall trapping is the most common method of ant capture in the western United States (Brandon Bestelmeyer, USDA ARS Jornada Experimental Range, and Thomas Crist, Miami University, personal communication). We placed 12 traps in each replicate plot. Six traps were placed randomly along each of 2 parallel $30-\mathrm{m}$ transect lines spaced $10 \mathrm{~m}$ apart. Pinflags were used to mark the trap locations. The traps were made of $120-\mathrm{mL}$, 6.5-cm-diameter disposable plastic sampling cups. A hole was dug at each random point on a transect line, and 2 empty sample cups, one inside the other, were placed into the hole (Bestelmeyer et al. 2000). The soil was smoothed around the lip of the bottom cup to make the cup flush with ground level. The top cup (filled with dirt and debris) was removed leaving a clean sample cup in the ground. Thirty milliliters of propylene glycol (antifreeze) was poured into each of the cups as a preservative. Propylene glycol has been shown neither to attract nor repel ants; therefore, it has been incorporated into standard ant sampling methods (Bestelmeyer et al. 2000). Unscented powdered laundry detergent was sprinkled on top of the propylene glycol to break the surface tension. Traps were left open in the field for 7 days.

To assure that we were not missing species that might avoid pitfall traps or that might only forage when attracted to food sources, we set trial bait traps-film canisters with mashed greasy potato chips in the bottom of each-in all plots at the intermediate tree cover sites. No ants were found in the canisters after 2 hours or after 4 hours. Therefore, we decided that bait traps were unnecessary in this study and that no ants at the potato chip baits meant that no Solenopsis invicta, the imported red fire ants, inhabit these sites (Jeff Knight, Nevada Department of Agriculture, Entomology Laboratory, personal communication).

Ant species richness and abundance were sampled prior to the burn in 2001 and after the burn in 2002. Because ant activity is regulated by soil moisture, sampling was conducted both early in the growing season, when soils were relatively wet, and late in the growing season, when soils were relatively dry. The first 2 sampling periods were conducted before the scheduled burn treatments from 18-20 June to 25-27 June 2001 and from 6-8 August to 13-14 August 2001. The second 2 sampling periods were conducted after the burn from 
11-12 June to 18-19 June 2002 and from 5-6 August to 12-13 August 2002.

Ant traps were collected, labeled, and stored at $4^{\circ} \mathrm{C}$ until processed. Samples were processed by pouring each sample through a $355-\mu \mathrm{m}$ sieve and retrieving the ants, which were then rinsed and preserved in ethanol. Samples were sorted, and ants were identified to species. We used keys in The Ants of Nevada (Wheeler and Wheeler 1986) as a reference. Jeff Knight, Nevada State Entomologist, and Philip Ward, University of California-Davis entomologist, helped with identifications. Philip Ward verified all reference specimens. Voucher specimens are deposited at the Nevada Department of Agriculture, Entomology Laboratory.

\section{Vegetation and Cover Variables}

Vegetation and cover variables were collected by Alicia Reiner (Reiner 2004). Understory vegetation data were sampled in fifty $1 \times$ 2-m microplots along belt transects within each of the 30 replicate plots along the elevation and tree cover gradients described above. Shrub and perennial bunchgrass and forb species were identified in each microplot. Two crown diameters and total plant height were measured for tree, shrub, and forb species. Two basal diameters and total plant height were measured for perennial bunchgrasses. The crown or basal diameter measurement pairs were converted into areas using standard algorithms. For each species measured, the crown or basal area was summed by plot and converted into a percent cover value (Reiner 2004).

The cover variables sampled and used in this study included aerial cover and ground cover values. Aerial cover values were obtained by summing plant species percent cover values for each vegetation type (tree, shrub, grass, and forb). Although tree cover continued to influence sites by providing some shade, these cover effects were greatly reduced post-fire and were not measured. Ground cover values were obtained by converting point count data (bare ground, gravel, and litter) into percent cover values (Reiner 2004). Ground cover variables were not measured on burn plots in 2002 .

Precipitation was collected in standing rain gages near the low-elevation sites $(2081 \mathrm{~m})$ and near the high-elevation sites $(2381 \mathrm{~m})$. Overwinter (OW; mid-October-May) and growing season (GS; May-mid-October) precipitation measurements were taken. Overwinter precipitation data for Underdown Canyon at the low-elevation gage $(2081 \mathrm{~m})$ are missing for the preburn year. Riley Canyon, an adjacent canyon with very similar precipitation values for both 2001 and 2002, received 10.0 $\mathrm{cm}$ of overwinter precipitation at $2102 \mathrm{~m}$ in 2001. Using the 2001 overwinter precipitation value for Riley Canyon, the precipitation regime (4 year-elevation combinations) for Underdown Canyon is as follows: preburn year, low elevation: $\mathrm{OW}=10.0 \mathrm{~cm}$, GS $=4.5$ $\mathrm{cm}$; preburn year, high elevation: $\mathrm{OW}=22.0$ $\mathrm{cm}$, GS $=6.0 \mathrm{~cm}$; post-burn year, low elevation: $\mathrm{OW}=21.0 \mathrm{~cm}, \mathrm{GS}=3.6 \mathrm{~cm}$; and postburn year, high elevation: $\mathrm{OW}=27.6 \mathrm{~cm}, \mathrm{GS}=$ $5.6 \mathrm{~cm}$.

\section{Data Analysis}

To examine the effects of elevation, tree cover, and burn treatment on ant abundance, we analyzed the data using mixed-model ANOVA (Proc Mixed, SAS 2002-2004). We used a 3-block, split-plot design where the 3 blocks were the 3 elevation classes (low, intermediate, and high) for the elevation analysis or the 3 tree cover classes (low, intermediate, and high) for the tree cover analysis. These blocks were split into 2 factors: burn treatment (burn and control) and year (preburn and post-burn). The elevation sites used in this study were located in only 1 canyon and were analyzed as a random effect to represent the range of elevation in the canyon, not just the elevation sampled. Therefore, we used best linear unbiased predictor (BLUP) estimates for the elevation variables (Littell et al. 2006). The tree cover classes (low, intermediate, and high) were fixed variables and were used as covariates for ant abundance. Backward stepwise regression was used after testing each variable with the full model. For all analyses, $P$-values $\leq 0.05$ indicated significance. Analyses performed using actual counts of total ant abundance produced nonhomogeneous variability. Therefore, total ant abundances were ln-transformed at the trap level to reduce the variability in capture rates.

We also examined the effects of elevation, tree cover, and burn treatment on the habitat variables using the same statistical models that we used for the ant data. We used BLUPs for the variables along the elevation gradient and backward stepwise regression for the variables within the tree cover classes as explained above. The variables examined in these analyses were 


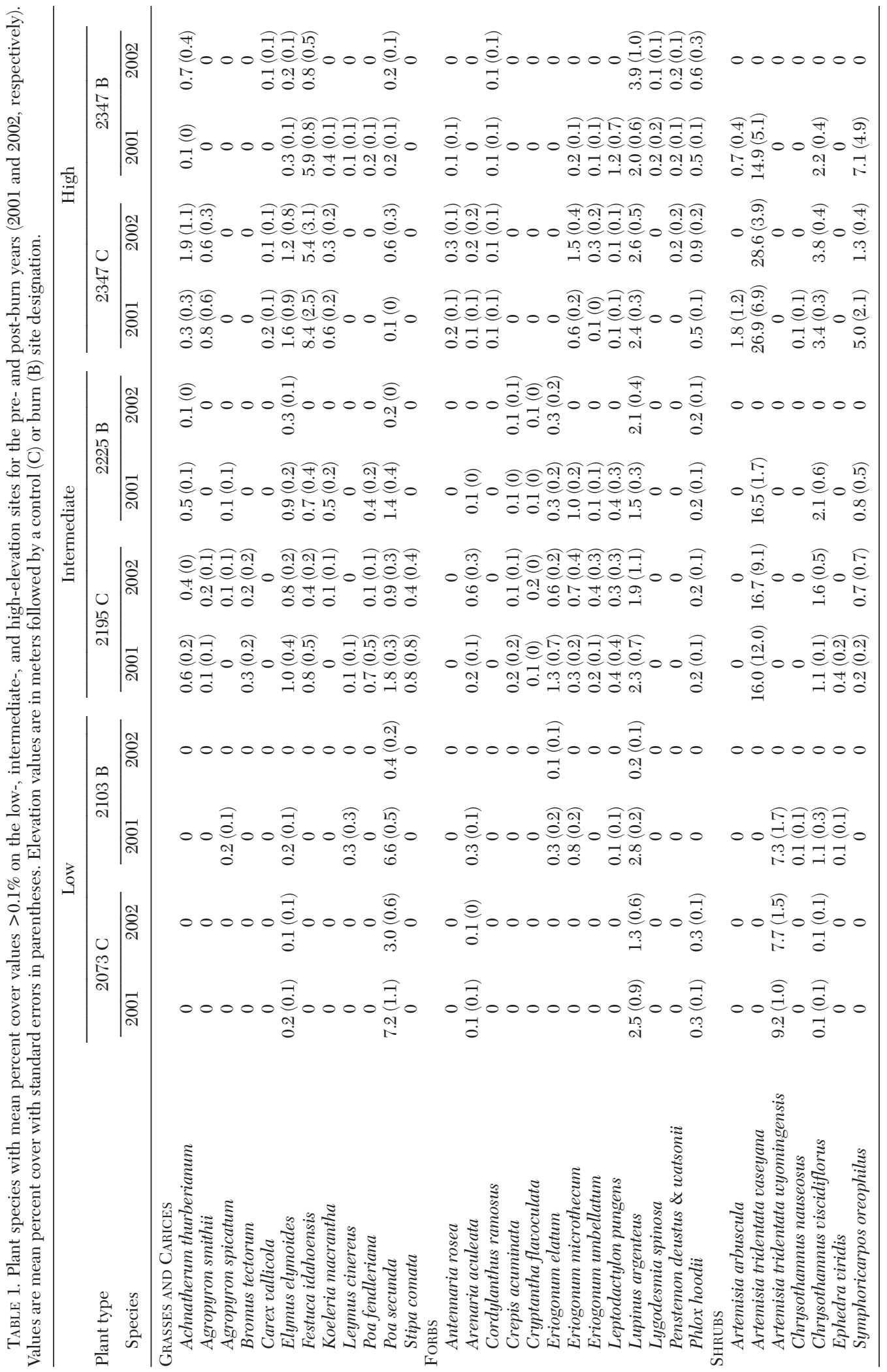


percent cover values for trees, shrubs, grasses, forbs, bare ground, gravel, and litter. We arcsine-transformed these percent cover values before we ran the analyses.

Ant species richness values did not vary widely. We plotted total ant species richness against ln-transformed abundance, elevation, and tree cover and observed no distinct patterns. Therefore, no further analyses were used to examine species richness.

We used cluster analyses (TWINSPAN; PCORD 1999) to examine patterns in ant species composition and plant species composition among sites. TWINSPAN is based on division of sequential reciprocal averaging ordinations. Ant or plant species were organized into groups using similarities in species abundance categories among sample locations. For ant species, we used raw abundance values at 6 dominance levels: 1-9, 10-19, 20-49, 50-99, 100-999, and $\geq 1000$. For plant species, we used percent cover values at 7 dominance levels: $0.01-0.019$, $0.02-0.09,0.10-0.49,0.50-0.99,1.00-4.99$, $5.00-9.99$, and $\geq 10.00$. Canonical correspondence analysis (CCA; PC-ORD 1999) was used to examine how ant communities are structured relative to vegetation and environmental variables. CCA is an ordination method in which the ordination of the samples and species is constrained by their relationships to environmental variables (McCune and Mefford 1999). The variables used in the CCA analyses were raw measures of ant abundance and percent cover values for trees, shrubs, grasses, forbs, bare ground, gravel, and litter. All default options were chosen for these analyses.

When TWINSPAN and CCA analyses revealed distinct ant community groups, ant species were assigned to functional groups. Ants can often be organized into functional groups using environmental factors in conjunction with behavioral characteristics to better elucidate the ecological roles of the groups (Andersen 1997). Functional group designations were modified from Andersen (1997) and Bestelmeyer and Schooley (1999) with the help of Brandon Bestelmeyer (personal communication). Ant species in our study were classified into 8 functional groups: (1) members of the genus Camponotus, which are usually nocturnal (Bestlemeyer and Schooley 1999); (2) distributions of cold-climate specialists, which are centered on the cool-temperate zone (Andersen 1997); (3) cryptic species, which forage pre- dominantly within the soil and litter and have little interaction with surface-foraging ants (Andersen 1997); (4) dominant cold-climate specialists, which are cold-climate specialists that are abundant, highly active, and aggressive (Wheeler and Wheeler 1986, Punttila et al. 1996); (5) generalized myrmicines, which are widespread genera occurring in most habitats and that rapidly recruit to, and successfully defend, clumped food resources (Andersen 1997); (6) hot-climate specialists, which are arid-adapted species (Andersen 1997); (7) opportunists, which are unspecialized, submissive species often common in disturbed habitats (Andersen 1997, Bestelmeyer and Schooley 1999); and (8) social parasites, which are species that prey upon other species or the resources of other species (Punttila et al. 1996, Wheeler and Wheeler 1986).

\section{RESUlts}

$$
\begin{gathered}
\text { Effects of Elevation, Treatment, } \\
\text { and Year }
\end{gathered}
$$

TWINSPAN ordination results for vegetation along the elevation gradient revealed almost perfect site separation of the sample locations in the preburn year. Plant species restricted to the low-intermediate range of the elevation gradient included the shrubs Artemisia tridentata wyomingensis and Ephedra viridis and the grass Agropyron spicatum (Table 1). Species restricted to the intermediate-high elevations included the shrubs Artemisia tridentata vaseyana, Artemisia arbuscula, and Symphoricarpos oreophilus and the grasses Festuca idahoensis and Koeleria macrantha. In the post-burn year the plant communities were divided primarily by burn or control treatment and secondarily by elevation. The burn treatment did not shift species community groups along the elevation gradient. Many of the species sampled prior to the burn were not apparent in the plots during the year following the burn (Table 1).

Results of the mixed-effects ANOVA on arcsine-transformed cover variables with BLUP estimate analyses for random effects showed significant differences in percent cover along the elevation gradient, as well as significant responses to treatment and year (Table 2). The most notable responses in the preburn year were the increase in shrub, bare ground, and litter cover values, and the decrease in tree and gravel cover values with increasing elevation 


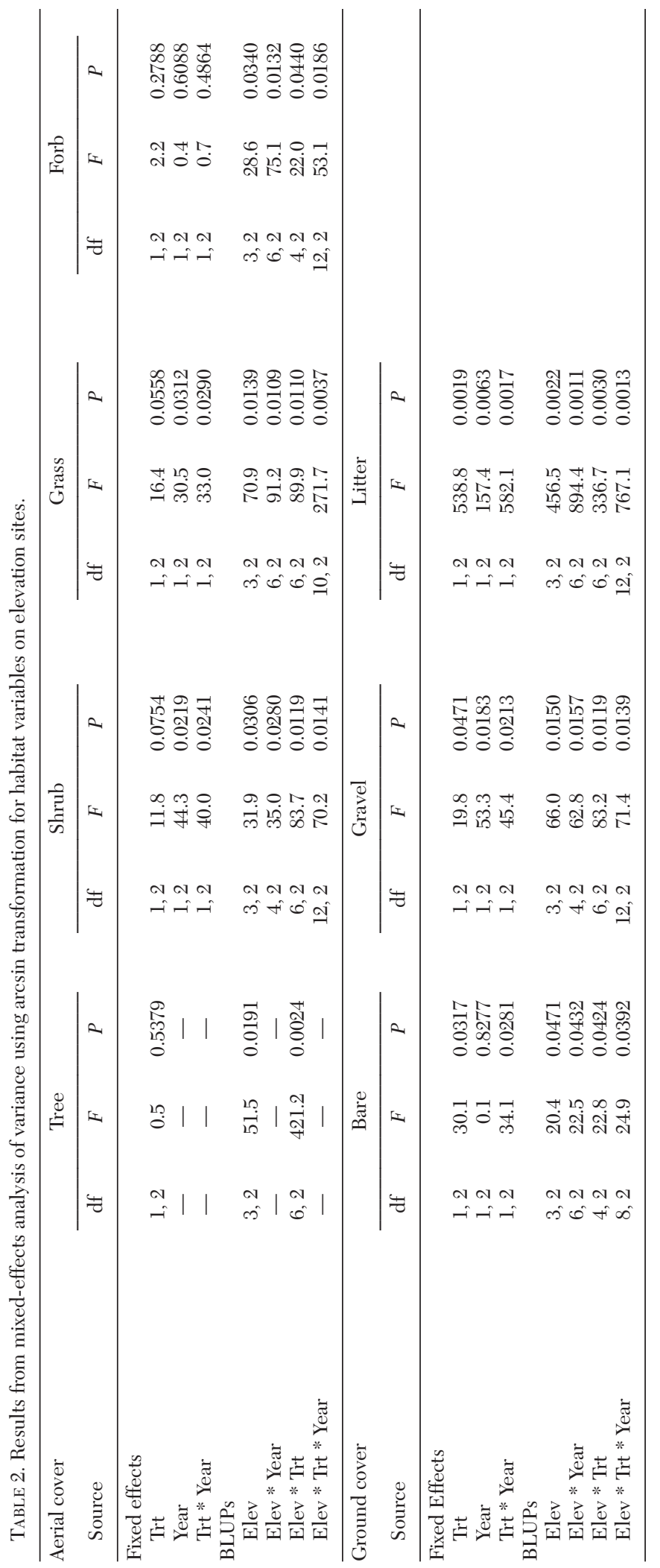


TABLE 3. Mean percent cover values (standard errors in parentheses) of habitat variables on the low-, intermediate-, and high-elevation sites for the pre- and post-burn years (2001 and 2002, respectively). Elevation values are in meters followed by control (C) or burn (B) site designation. Dashes represent uncollected data.

\begin{tabular}{|c|c|c|c|c|c|c|c|}
\hline \multirow[b]{2}{*}{ Cover type } & \multirow[b]{2}{*}{ Year } & \multicolumn{2}{|c|}{ Low } & \multicolumn{2}{|c|}{ Intermediate } & \multicolumn{2}{|c|}{ High } \\
\hline & & $2073 \mathrm{C}$ & $2103 \mathrm{~B}$ & $2195 \mathrm{C}$ & $2225 \mathrm{~B}$ & $2347 \mathrm{C}$ & 2347 B \\
\hline \multicolumn{8}{|l|}{ Aerial cover } \\
\hline Tree & $\begin{array}{l}2001 \\
2002\end{array}$ & $\begin{array}{c}52.8(2.7) \\
-\end{array}$ & $\begin{array}{c}44.0(7.0) \\
-\end{array}$ & $\begin{array}{c}35.7(4.5) \\
-\end{array}$ & $\begin{array}{c}40.8(5.9) \\
-\end{array}$ & $\begin{array}{c}12.0(2.2) \\
-\end{array}$ & $\begin{array}{c}33.8(3.1) \\
-\end{array}$ \\
\hline Shrub & $\begin{array}{l}2001 \\
2002\end{array}$ & $\begin{array}{l}9.2(0.7) \\
7.8(1.4)\end{array}$ & $\begin{array}{r}9.5(2.1) \\
0\end{array}$ & $\begin{array}{l}18.7(2.8) \\
20.1(1.9)\end{array}$ & $\begin{array}{r}20.8(1.9) \\
0\end{array}$ & $\begin{array}{l}37.9(7.8) \\
35.3(4.2)\end{array}$ & $\begin{array}{r}26.6(9.8) \\
0\end{array}$ \\
\hline Grass & $\begin{array}{l}2001 \\
2002\end{array}$ & $\begin{array}{l}7.6(1.0) \\
3.1(0.6)\end{array}$ & $\begin{array}{l}7.3(0.3) \\
0.4(0.2)\end{array}$ & $\begin{array}{l}6.1(0.7) \\
3.6(0.2)\end{array}$ & $\begin{array}{r}4.6(0) \\
0.5(0.2)\end{array}$ & $\begin{array}{l}12.2(0.7) \\
10.0(1.4)\end{array}$ & $\begin{array}{l}7.2(0.6) \\
1.9(0.8)\end{array}$ \\
\hline Forb & $\begin{array}{l}2001 \\
2002\end{array}$ & $\begin{array}{l}3.0(1.0) \\
1.8(0.8)\end{array}$ & $\begin{array}{l}4.1(0.4) \\
0.3(0.1)\end{array}$ & $\begin{array}{l}5.1(1.2) \\
4.5(1.8)\end{array}$ & $\begin{array}{l}2.7(0.3) \\
2.7(0.6)\end{array}$ & $\begin{array}{l}3.5(0.6) \\
4.9(0.8)\end{array}$ & $\begin{array}{l}3.4(0.7) \\
4.9(1.2)\end{array}$ \\
\hline \multicolumn{8}{|c|}{ Ground cover } \\
\hline Bare & $\begin{array}{l}2001 \\
2002\end{array}$ & $\begin{array}{l}1.5(0.9) \\
7.5(1.8)\end{array}$ & $\begin{array}{l}1.2(0.9) \\
-\end{array}$ & $\begin{array}{r}1.8(0.9) \\
22.8(11.3)\end{array}$ & $\begin{array}{c}4.4(3.0) \\
-\end{array}$ & $\begin{array}{l}11.8(6.7) \\
20.5(2.2)\end{array}$ & $\begin{array}{c}10.8(3.5) \\
-\end{array}$ \\
\hline Gravel & $\begin{array}{l}2001 \\
2002\end{array}$ & $\begin{array}{l}42.7(2.6) \\
43.4(0.8)\end{array}$ & $\begin{array}{c}41.3(4.5) \\
-\end{array}$ & $\begin{array}{r}34.6(2.9) \\
31.5(11.4)\end{array}$ & $\begin{array}{c}32.6(4.2) \\
-\end{array}$ & $\begin{array}{l}15.7(6.8) \\
12.6(3.7)\end{array}$ & $\begin{array}{c}17.3(4.0) \\
-\end{array}$ \\
\hline Litter & $\begin{array}{l}2001 \\
2002\end{array}$ & $\begin{array}{l}43.2(1.4) \\
48.6(2.2)\end{array}$ & $\begin{array}{c}39.8(2.8) \\
-\end{array}$ & $\begin{array}{l}46.1(3.0) \\
40.6(2.1)\end{array}$ & $\begin{array}{c}45.8(2.3) \\
-\end{array}$ & $\begin{array}{l}50.2(1.8) \\
49.2(3.5)\end{array}$ & $\begin{array}{c}51.8(3.7) \\
-\end{array}$ \\
\hline
\end{tabular}

(Table 3). The most notable responses in the post-burn year were the decrease in grass cover on control, but especially burn plots, and the increase in bare ground on all control plots (Table 3).

We found 32 species of ants from 17 genera and 3 subfamilies, but only 29 of these species were included in the analyses (Appendixes 1, 2, Fig. 2) due to identification problems with certain Formica, Myrmica, and Lasius species. Formica obscuripes was included with Formica integroides, Myrmica sp. near fracticornis was included with Myrmica tahoensis, and Lasius niger was included with Lasius sitiens. Also, the characteristic used to distinguish between Formica manni and Formica neogagates was color. Solid black individuals were identified as F. neogagates and bicolored individuals were identified as F. manni. Color is highly variable in these desert species (Ward personal communication), but because they separated nicely with elevation, they were treated as distinct species. The number of ant species found in Underdown Canyon was comparable to numbers reported in other studies of arid ecosystems (Bestelmeyer and Wiens 2001, Sanders et al. 2003).

TWINSPAN ordination results for ant species in both years showed that elevation sites could be organized by ant community composition, with distinct communities at the low-intermediate and intermediate-high elevations (Fig. 2). The ant species that made up these communities came from different functional groups. The low-intermediate elevations were characterized by generalized myrmicines such as Crematogaster mormonum, opportunists such as Aphaenogaster occidentalis, and hotclimate specialists such as Myrmecocystus testaceus and Pogonomyrmex occidentalis. The intermediate-high elevation sites were characterized by dominant cold-climate specialist species that build thatch mounds such as Formica integroides and F. ravida, and opportunists like Myrmica tahoensis and Formica subpolita. Ubiquitous species comprised many functional groups and included Camponotus vicinus, Formica argentea, and Temnothorax nevadensis. Species found in very small abundances were assigned to the rare category. These included species from the genera Brachymyrmex, Pheidole, Stenamma, and Formicoxenus. The species that made up these communities did not change post-burn.

Results of the mixed-effects ANOVA on lntransformed ant abundance with BLUP estimate analyses for random effects showed significant differences in abundance along the elevation gradient (Table 4). The abundance of individuals increased with increasing elevation in both years (Fig. 3). The results also showed a significant elevation $x$ treatment $x$ 


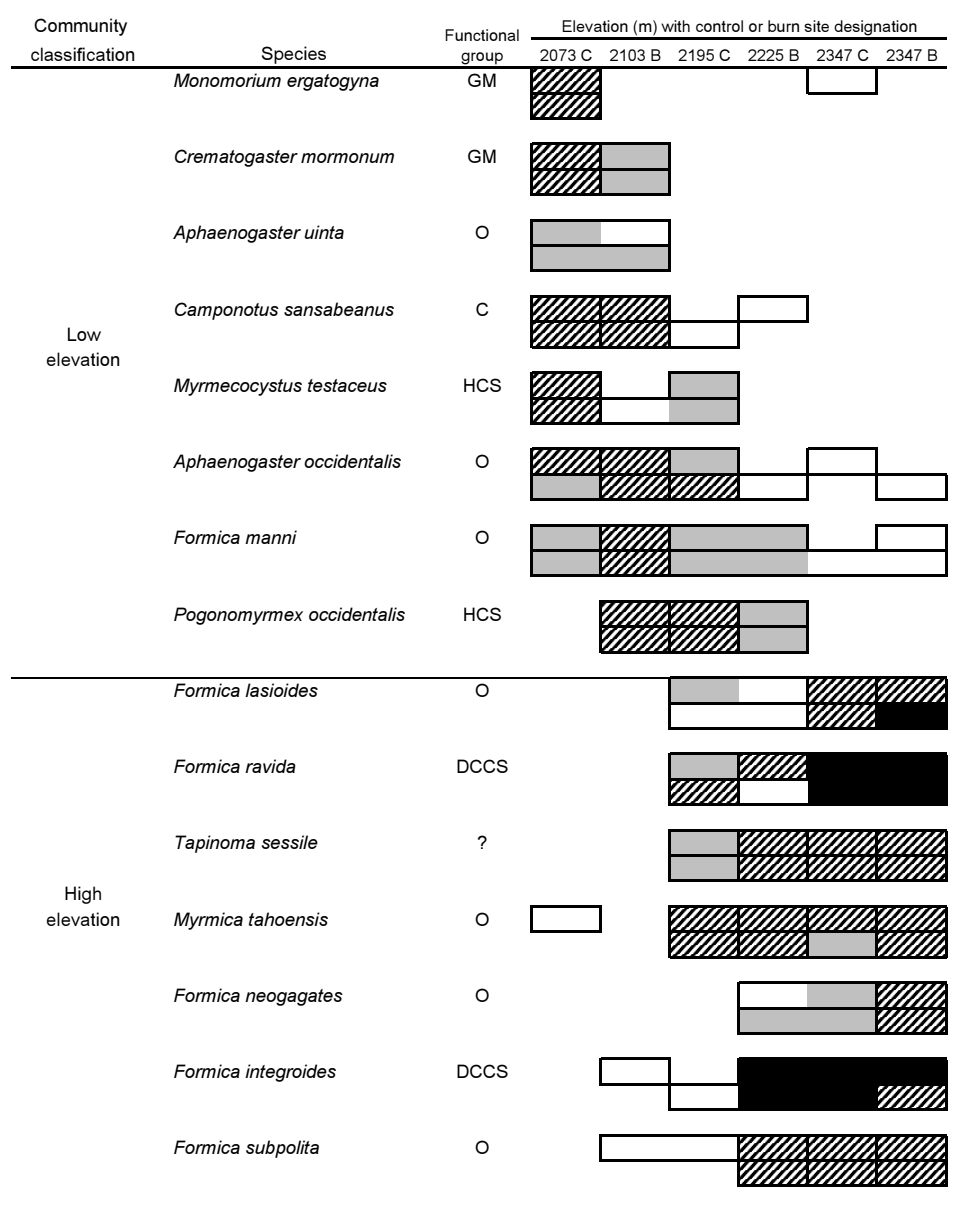

Fig. 2. Ant community composition along the elevation gradient. Ant species found in abundance of $\geq 10$ on the intermediate-elevation sites and below are considered low-elevation species. Ant species found in abundance of $\geq 10$ on the intermediate-elevation sites and above are considered high-elevation species. Abundance color codes are the following: white 1-9, light grey 10-99, hatched 100-999, black 1000+. Top bars indicate species abundance in 2001 and bottom bars indicate species abundance in 2002. Functional groups are the following: $\mathrm{C}=$ Camponotus, $\mathrm{CCS}=$ cold-climate specialists, $\mathrm{CrS}=$ cryptic species, DCCS $=$ dominant cold-climate specialists, GM = generalized Myrmicinae, HCS $=$ hotclimate specialists, $\mathrm{O}=$ opportunists, $\mathrm{SP}=$ social parasites.

year interaction, indicating an effect of fire that differed between elevation sites (Table 4). Ant abundance decreased from the preburn year to the post-burn year on control sites at all elevations, while abundance increased on the burn sites at the intermediate and high elevations and remained the same at the low elevations (Fig. 3).

Although ant and plant communities both showed site separation along the elevation gradient, CCA analyses of environmental variables for all plots in 2001 showed that ant community groupings were more strongly associated with elevation and percent tree cover along the elevation gradient than with understory vegetation (Fig. 4). CCA analyses of control plots on the elevation sites in 2002 yielded the same results. The $\mathrm{R}^{2}$ values generated from the analyses for the environmental variables revealed that elevation was the only significant variable associated with ant species organization on all plots in $2001\left(\mathrm{R}^{2}=0.697\right.$, $\mathrm{df}=$ $16, P \leq 0.01)$. Comparing the burn plots in the pre- and post-burn years using CCA analyses revealed little change post-burn. The ordination on burn plots showed that ant species were primarily associated with ground cover and elevation in both years. 


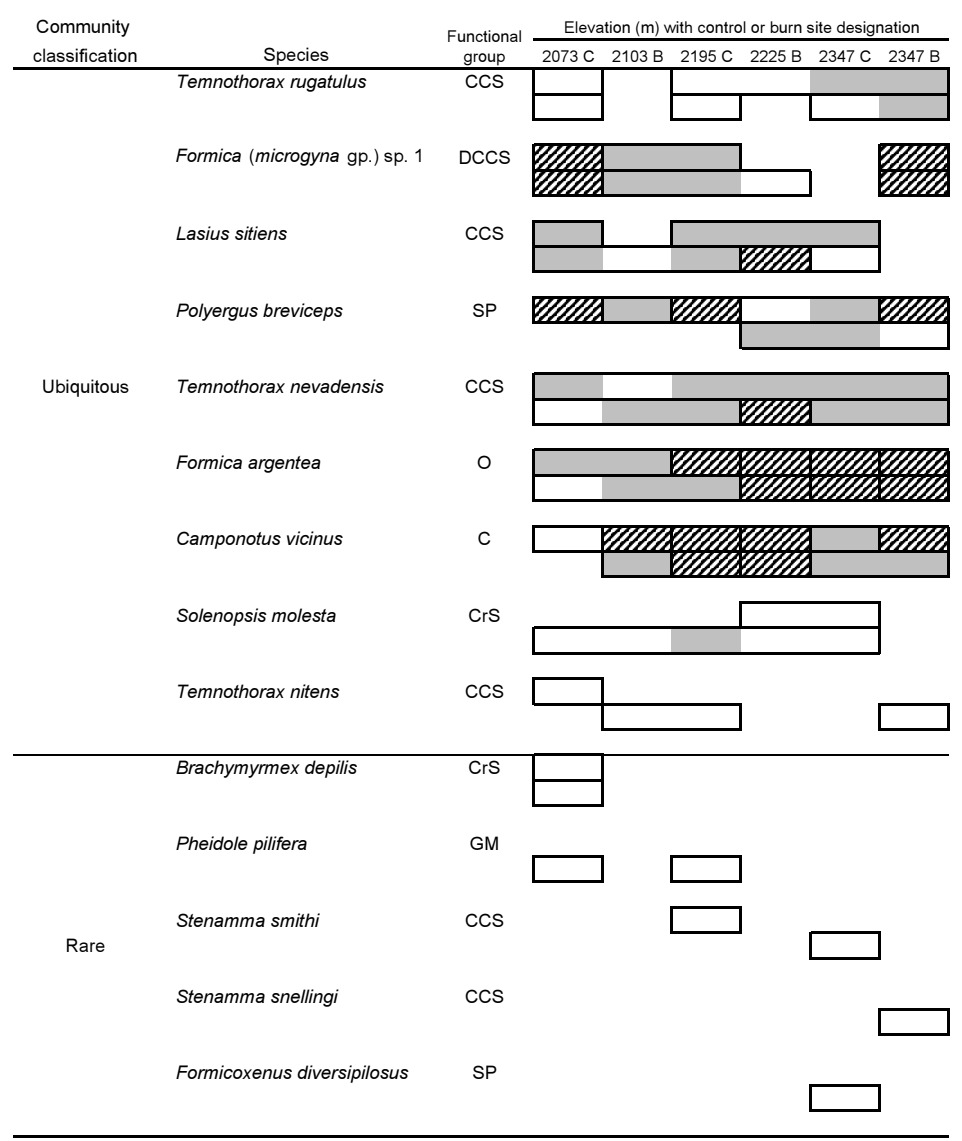

Fig. 2. Continued.

TABLE 4. Results from the mixed-effects ANOVA for lntransformed ant abundance on elevation sites. Sources include fixed-effects and best linear unbiased predictors (BLUPs) for random effects.

\begin{tabular}{lrrc}
\hline Source & df & \multicolumn{1}{c}{$F$} & $P$ \\
\hline Fixed effects & & & \\
$\quad$ Trt & 1,2 & 0.2 & 0.6965 \\
Year & 1,2 & 4.1 & 0.1788 \\
$\quad$ Trt * Year & 1,2 & 7.9 & 0.1064 \\
BLUPs & & & \\
Elev * Year & 3,2 & 38.1 & 0.0257 \\
Elev * Year & 4,2 & 29.6 & 0.0329 \\
Elev * Trt & 6,2 & 102.6 & 0.0097 \\
Elev * Trt *ear & 12,2 & 58.8 & 0.0169 \\
\hline
\end{tabular}

Effects of Tree Cover, Treatment, and Year

TWINSPAN ordination results revealed a distinct separation between the burn and control tree cover plots according to plant species in 2001; however, plant community groups were not so distinct. These results also show a separation of the high tree cover plots from the rest of the plots. Some species were not found in, or had lower percent cover values in, the high tree cover plots. These species included the forbs Eriogonum microthecum, E. umbellatum, E. elatum, and Crepis accuminata, the grass Agropyron spicatum, and the shrubs Artemisia tridentata vaseyana and Chrysothamnus viscidiflorus. The plots remained sorted by control or burn site in the post-burn year, with many of the plant species completely absent from the burn plots. Again, there was an additional separation of high tree cover plots from all other plots within each site.

Results of the mixed-effects ANOVA on arcsine-transformed cover variables showed significant differences in percent cover along the tree cover gradient, as well as in response to differences in treatment and year (Table 5). As 


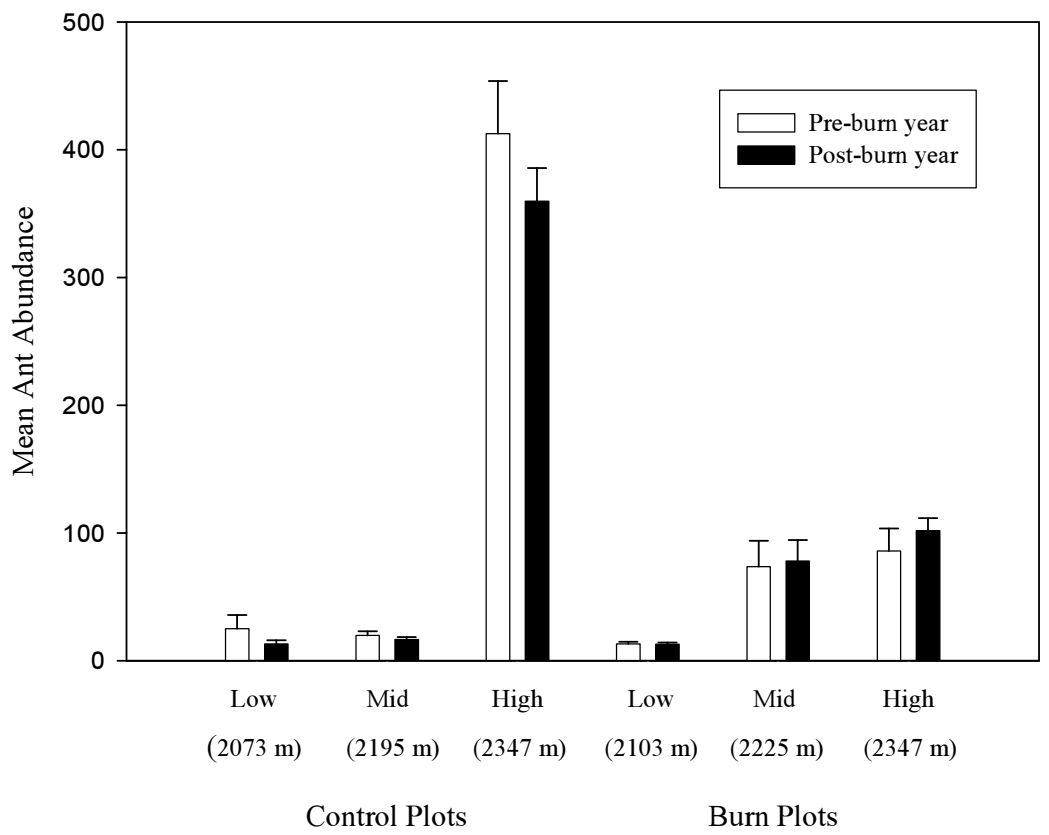

Fig. 3. Mean ant abundance for the control and burn plots at low, intermediate, and high elevations. Bars represent $1 s_{\bar{x}}$.

tree cover increased along the gradient from low tree cover plots to high tree cover plots on both control and burn sites in 2001, litter increased and shrub, grass, forb, bare ground, and gravel cover decreased (Table 6). These patterns remained the same in the 2 nd year. As with the elevation plots, percent grass cover decreased on both control and burn tree cover plots from 2001 to 2002.

Of the 29 ant species that were found on the elevation plots, 26 were found on the tree cover plots (Appendixes 3, 4). TWINSPAN ordination results showed that tree cover in the preburn year did not effect any clear patterns of ant community organization. TWINSPAN ordinations for these plots in the post-burn year separated the control and burn plots and, secondarily, separated the high tree cover plots from the low and intermediate tree cover plots. On high tree cover plots, abundance tended to decrease for some ant species, like Formica lasioides and F. manni, and abundance tended to increase for others, like Myrmecocystus testaceus. Some species, like Aphaenogaster occidentalis and Camponotus sansabeanus, were found predominantly in control plots, while others, such as Formica integroides and F. subpolita, were found predominantly in the burn plots.
Results from the mixed-effects ANOVA on ln-transformed ant abundance along the tree cover gradient revealed no significant responses related to tree cover. It did, however, yield a significant result for the treatment $\times$ year interaction when the full model $\left(F_{1,22}=4.3, P\right.$ $=0.0490)$ was used, indicating a fire effect, and a significant response to treatment when the reduced model $\left(F_{1,26}=6.6, P=0.0164\right)$ was used, indicating a general difference between the control and burn sites. The treatment $x$ year interaction that we observed along the tree cover gradient was the same as it was along the elevation gradient; individual ant abundance decreased in the 2nd year on control plots and increased in the 2nd year on burn plots. Ant abundance was lowest on high tree cover plots for burn and control sites in both years, although this result was not significant using mixed-effects analysis.

The CCA analysis for all tree cover plots in 2001 showed that ants are not clearly associated with any of the environmental variables. CCA analyses of the control plots for the postburn year yielded similar results. The only variable with a significant $R^{2}$ value for all tree cover plots in 2001 was bare ground cover $\left(\mathrm{R}^{2}\right.$ $=0.808, \mathrm{df}=16, P \leq 0.01)$. Comparing burn plots in the pre- and post-burn years using 

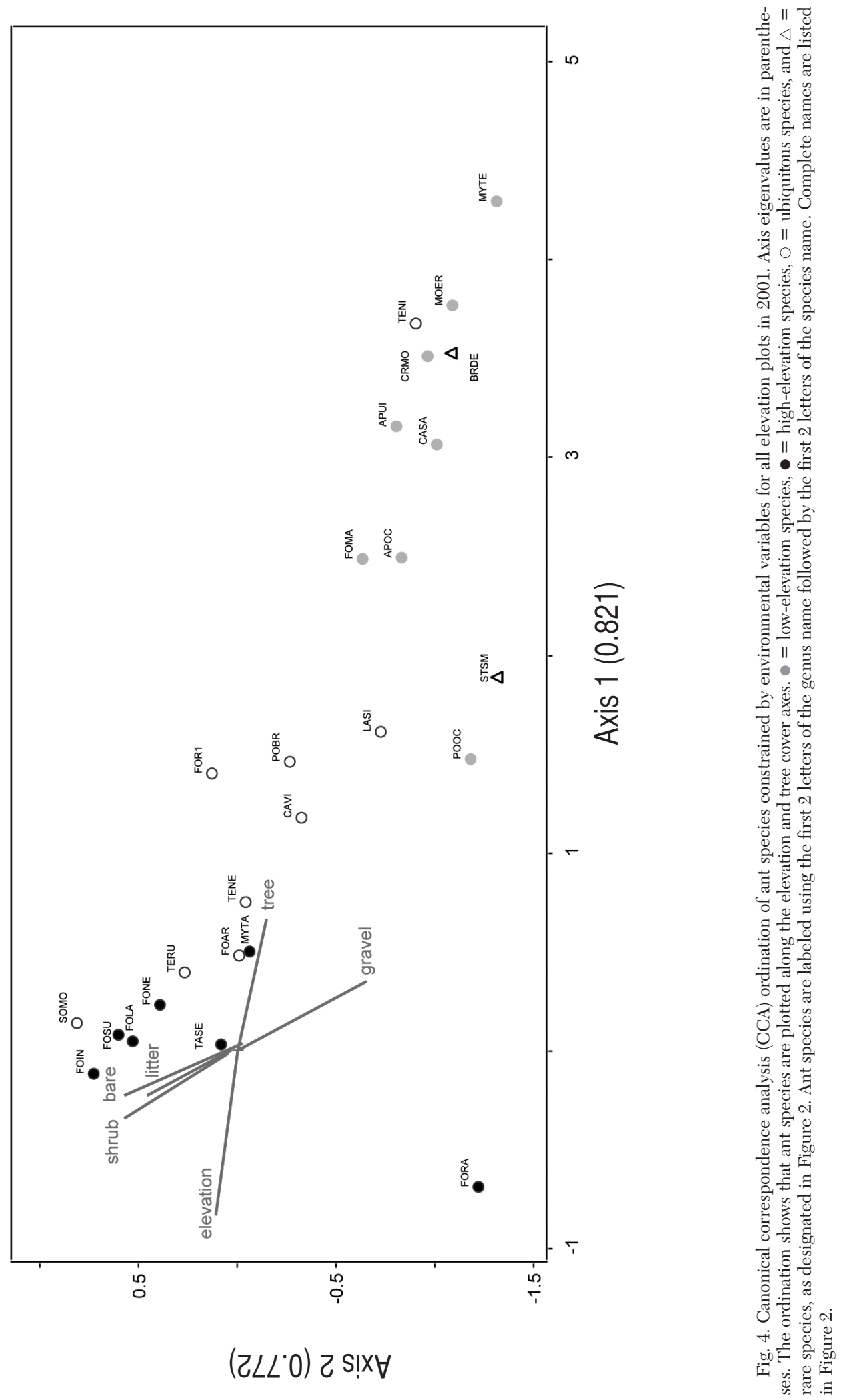


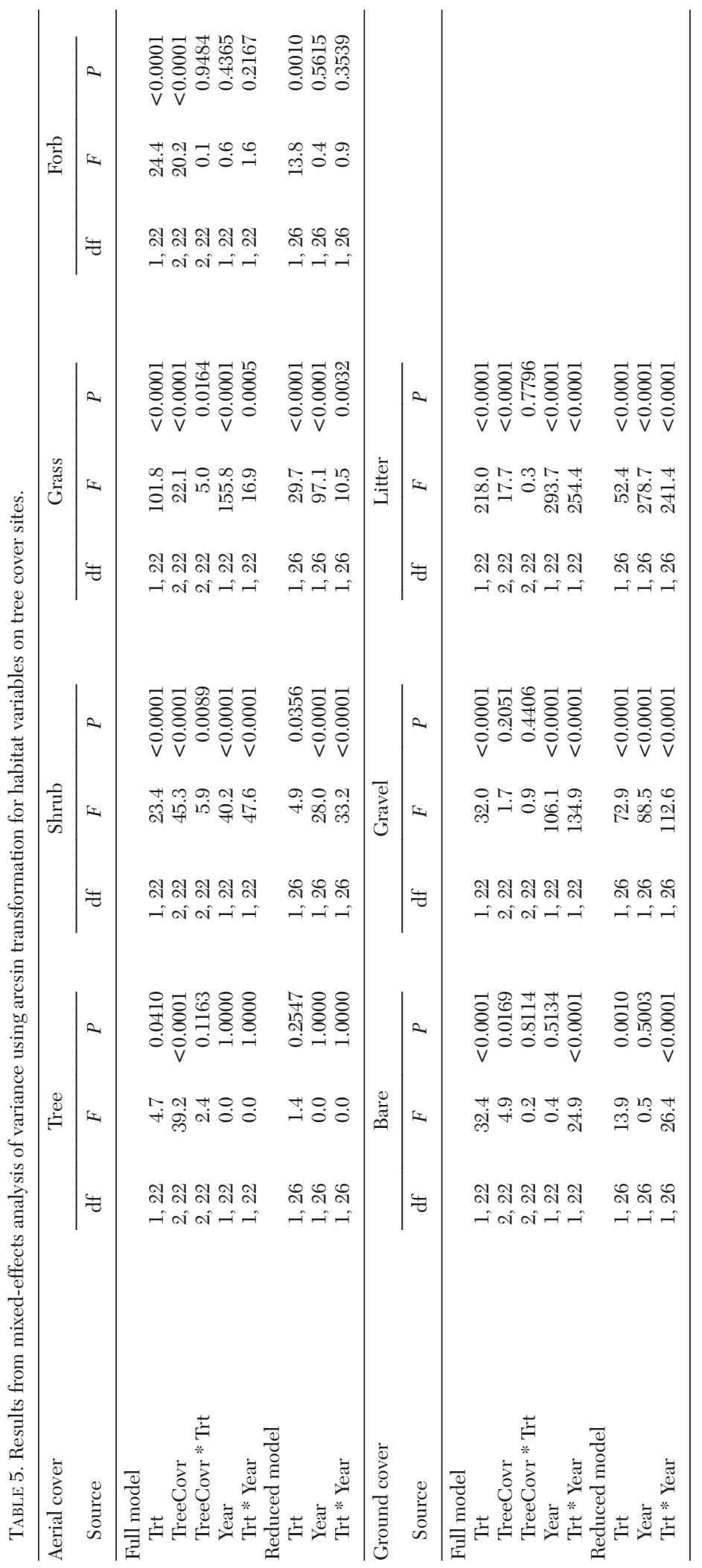


TABLE 6. Mean percent cover values (standard errors in parentheses) of habitat variables on the low, intermediate, and high tree cover plots for the pre- and post-burn years (2001 and 2002, respectively). Dashes represent uncollected data.

\begin{tabular}{|c|c|c|c|c|c|c|c|}
\hline \multirow[b]{2}{*}{ Cover type } & \multirow[b]{2}{*}{ Year } & \multicolumn{3}{|c|}{ Control plots } & \multicolumn{3}{|c|}{ Burn plots } \\
\hline & & Low & Intermediate & High & Low & Intermediate & High \\
\hline \multicolumn{8}{|l|}{ Aerial cover } \\
\hline Tree & $\begin{array}{l}2001 \\
2002\end{array}$ & $\begin{array}{c}17.9(6.7) \\
-\end{array}$ & $\begin{array}{c}35.7(4.5) \\
-\end{array}$ & $\begin{array}{c}75.1(6.3) \\
-\end{array}$ & $\begin{array}{c}21.3(3.8) \\
-\end{array}$ & $\begin{array}{c}40.8(5.9) \\
-\end{array}$ & $\begin{array}{c}80.6(2.6) \\
-\end{array}$ \\
\hline Shrub & $\begin{array}{l}2001 \\
2002\end{array}$ & $\begin{array}{l}33.8(4.3) \\
35.9(3.8)\end{array}$ & $\begin{array}{l}18.7(2.8) \\
20.1(1.9)\end{array}$ & $\begin{array}{l}1.3(1.2) \\
1.6(1.3)\end{array}$ & $\begin{array}{r}42.1(3.5) \\
0\end{array}$ & $\begin{array}{r}20.8(1.9) \\
0\end{array}$ & $\begin{array}{r}4.1(1.8) \\
0\end{array}$ \\
\hline Grass & $\begin{array}{l}2001 \\
2002\end{array}$ & $\begin{array}{r}10.1(2.1) \\
6.4(0.7)\end{array}$ & $\begin{array}{l}6.1(0.7) \\
3.6(0.2)\end{array}$ & $\begin{array}{l}4.7(0.4) \\
1.9(0.5)\end{array}$ & $\begin{array}{l}4.3(0.1) \\
0.8(0.1)\end{array}$ & $\begin{array}{r}4.6(0) \\
0.5(0.2)\end{array}$ & $\begin{array}{l}2.8(0.1) \\
0.2(0.1)\end{array}$ \\
\hline Forb & $\begin{array}{l}2001 \\
2002\end{array}$ & $\begin{array}{l}6.3(0.3) \\
7.2(1.0)\end{array}$ & $\begin{array}{l}5.1(1.2) \\
4.5(1.8)\end{array}$ & $\begin{array}{l}0.9(0.3) \\
1.2(0.2)\end{array}$ & $\begin{array}{l}4.2(0.5) \\
3.1(0.5)\end{array}$ & $\begin{array}{l}2.7(0.3) \\
2.7(0.6)\end{array}$ & $\begin{array}{r}0.4(0.2) \\
0.1(0)\end{array}$ \\
\hline \multicolumn{8}{|c|}{ Ground cover } \\
\hline Bare & $\begin{array}{l}2001 \\
2002\end{array}$ & $\begin{array}{r}5.1(0.8) \\
12.3(0.8)\end{array}$ & $\begin{array}{r}1.8(0.9) \\
22.8(11.3)\end{array}$ & $\begin{array}{l}2.0(0.8) \\
4.2(0.7)\end{array}$ & $\begin{array}{c}4.8(1.6) \\
-\end{array}$ & $\begin{array}{c}4.4(3.0) \\
-\end{array}$ & $\begin{array}{c}0.1(0.1) \\
-\end{array}$ \\
\hline Gravel & $\begin{array}{l}2001 \\
2002\end{array}$ & $\begin{array}{l}31.2(3.4) \\
42.5(5.0)\end{array}$ & $\begin{array}{r}34.6(2.9) \\
31.5(11.4)\end{array}$ & $\begin{array}{l}28.0(3.9) \\
32.1(9.0)\end{array}$ & $\begin{array}{c}37.5(1.0) \\
-\end{array}$ & $\begin{array}{c}32.6(4.2) \\
-\end{array}$ & $\begin{array}{c}25.3(1.0) \\
-\end{array}$ \\
\hline Litter & $\begin{array}{l}2001 \\
2002\end{array}$ & $\begin{array}{l}44.2(3.9) \\
38.6(2.5)\end{array}$ & $\begin{array}{l}46.1(3.0) \\
40.6(2.1)\end{array}$ & $\begin{array}{l}58.1(2.8) \\
60.5(7.0)\end{array}$ & $\begin{array}{c}41.1(2.7) \\
-\end{array}$ & $\begin{array}{c}45.8(2.3) \\
-\end{array}$ & $\begin{array}{c}69.8(2.4) \\
-\end{array}$ \\
\hline
\end{tabular}

CCA analyses reveals little change in ant communities post-burn. In both years, few of the habitat variables were associated with ant abundance, and patterns of ant community organization were not distinct.

\section{Discussion}

According to TWINSPAN and CCA analyses, distinct low- and high-elevation ant communities exist in Underdown Canyon. The lowelevation community comprises hot-climate specialists, generalized myrmicines, opportunists, and 1 Camponotus species; it includes 8 ant species: Monomorium ergatogyna, Crematogaster mormonum, Aphaenogaster unita, A. occidentalis, Camponotus sansabeanus, Myrmecocystus testaceus, Formica manni, and Pogonomyrmex occidentalis. The environmental characteristics that define this community are lower elevation, increased tree cover, and gravel ground cover. The high-elevation community comprises dominant cold-climate specialists and opportunists and includes 7 species: Formica lasioides, F. ravida, F. neogagates, F. integroides, F. subpolita, Tapinoma sessile, and Myrmica tahoensis. The defining environmental characteristics for this community are higher elevation, increased shrub cover, and increased bare and litter ground cover. Although plant species exhibited similar patterns in TWINSPAN analyses, vegetation did not seem to be a driving factor for ant commu- nity organization. These results persisted postfire. Whitford et al. (1999) and Bestelmeyer and Wiens (2001) also found that ant communities did not vary consistently with vegetation classification or disturbance but did vary with changes in soil texture.

Opportunists, cold-climate specialists, social parasites, cryptic species, 1 Camponotus species, and 1 dominant cold-climate specialist were found across all elevations. No hot-climate specialists were found at the 2 high-elevation sites, and no generalized myrmicines, with the exception of 1 individual, were found at the intermediate-high-elevation sites. Hot-climate specialists are adapted to arid environments, and generalized myrmicines are predominant at desert sites (Andersen 1997). This suggests that the lower elevations had real ecological differences that resulted in ant community differences. A drier moisture regime in the lowelevation sites would affect soil texture, plant communities, and ant activity. Since many of the functional group classifications were modified from ant functional groups in other parts of the world, especially Australia, it is possible that the functional group classification scheme used here is too broad and does not accurately reflect the ecological roles of ant species in Underdown Canyon. One example that demonstrates this potential problem is that Formica manni is labeled as an opportunist in Andersen's modified functional group classification for North American ants (1997), but this species 
is known by local myrmecologists to be a xerophilic or thermophilic species (Ward personal communication).

Ant activity also varied along the elevation gradient. If we were to rearrange the columns in Figure 3 by elevation, placing the high-elevation control plot last (as in Fig. 1), we would see that ant abundance steadily increases with elevation, terminating at our farthest site where the greatest abundance of ants was found. More mesic conditions at higher elevations, which result in greater soil moisture, could cause the abundance of individual ants to increase because of increased levels of primary production and decreased levels of physiological stress, such as desiccation. Sanders et al. (2003) suggested that this was the case for increases in ant species richness at high elevations in their arid Nevada locations. Increased precipitation also allows for a greater capacity to support vegetation, including shrubs. The dominant cold-climate specialists, our most abundant group of ant species, are thatch builders that collect honeydew from aphidtending on shrubs (McIver and Yandell 1998). More shrubs at higher elevations means that more of the dominant and highly abundant ant species will be present. This would explain why ant communities were most strongly associated with the elevation and tree cover variables in our CCA analyses. As elevation increased, tree cover decreased, resulting in increased cover of other types of vegetation, such as shrubs. The abundance of ants at our final site (high-elevation control) was so much greater than abundance at the other sites because of an overwhelming increase in thatchbuilding species (Appendixes 1,2). Not surprisingly, this site also exhibited over 10\% greater shrub cover than the high-elevation burn site (Table 3).

Studies of other taxa show similar responses to elevation gradients in Great Basin montane environments. Fleishman et al. (1998) found higher butterfly species richness at intermediate elevations due to more favorable conditions. In 2 canyons adjacent to our study canyon, Fleishman et al. (2000) found that butterfly species richness increased with elevation in 1 mountain range and decreased in another. They concluded that climatic gradients were range-specific. These results suggest that a strong elevation gradient exists for invertebrates, regardless of variability within the system.
Tree cover itself had no significant association with ant populations, although ant populations tended to have the lowest abundances in the high tree cover plots. This observation could simply be due to the possibility that ants might not be as easily trapped where larger litter mats allow for more dimensions in which to forage and avoid traps. The differences in composition and abundance between control and burn plots are most likely due to a difference in elevation. We tried to control for differences in elevation along the tree cover gradient by placing the control and burn plots in the intermediate elevation range of the canyon. The burn plots were located only $30 \mathrm{~m}$ higher in elevation than the control plots (Fig. 1). Although this difference seems minor, the burn plots have more in common with the high-elevation plots from the elevation study, and the control plots have more in common with the low-elevation plots. Ant species assemblages tended to be organized more by location on the alluvial fans rather than by tree cover. Plant groupings often showed this same pattern. Trees are expanding into the existing sagebrush ecosystem, and our tree cover classes are an artificial construct of that process. Ant and plant species organization most likely reflects the remnant sagebrush community and local heterogeneity on the fan. Local tree cover will not reflect true habitat differences when too much spatial variability exists within a site. However, we did see a decrease in plant species and percent cover values in the high tree cover plots. If this pattern continues with the expansion of the woodland, then we might expect to see a decline in understory-dependent species.

Following the fire treatment, the number of individual ants in pitfall traps did increase on burn plots while they decreased on control plots, indicating a burn effect that was significant using BLUP analysis only (Table 4). Ant abundance likely decreased on control plots because there was less precipitation in the 2 nd year. No post-fire changes in community composition or richness were observed. These results are consistent with the Idaho and New Mexico studies of ant community response to fire (Zimmer and Parmenter 1998, Bliss et al. 1999) and are also consistent with Ratchford et al. (2005), who found that ant species composition depended on habitat type rather than on disturbance by fire. Increases in ant activity following fire have been previously documented 
(Andersen and Yen 1985, Majer 1997, Andersen and Müller 2000, York 2000, Farji-Brener et al. 2002). Fire often has little direct effect on ant populations because of their ability to take refuge in underground nests. Fire modifies habitat structure and food resources, which can affect ant population response (Andersen 1991). Decreases in litter biomass and increases in ground surface insolation can increase the likelihood of ant capture (Andersen and Müller 2000) or "trapability" (York 2000). The burns were conducted in the spring when soil moisture was higher. Increased soil moisture contributes to greater patchiness in burn severity. Higher-severity burns in midsummer or fall might have had increased effects on both vegetation and ants.

As mentioned earlier, this study was conducted in only 1 canyon. With additional sampling in adjacent canyons we might expect to find variability in ant species composition, richness, and abundance, but we would expect the patterns of changes in ant communities to remain the same overall. That is, changes in ant communities along elevation gradients are based primarily on climatic gradients rather than on vegetation communities. We would also expect to find greater changes in ant communities with hotter fires that cover larger areas. With much of the spatial area around and between burn sites remaining intact, it seems likely that ants could easily escape any detrimental effects from the prescribed burn.

\section{Implications for Management and Conservation}

Elevation was most closely associated with differences in ant community composition and abundance. Also, ants were resilient to the fire 1 season after the prescribed burn. Further sampling in subsequent years would reveal whether or not this is a lasting effect. It is noteworthy that most ant nests in the study plots survived the fire and remained active throughout the season. Some thatch nests built by Formica species had completely burned. Yet, colony relocation and the construction of new thatch mounds were witnessed at many locations within burned sites. If plant growth, regeneration, and seedling establishment occurred following the fire, we would assume that ant species would remain largely unaffected by this fire. However, many thatching ants fulfill most of their dietary needs by tend- ing aphids on sagebrush (McIver and Yandell 1998). If the surrounding sage plants do not reestablish quickly, the thatching ant colonies could, over time, experience a decline in abundance or even colony demise.

Although ants were not significantly affected by differences in tree cover, we did see a decline in percent cover of some plant species as tree cover increased. Tree expansion over large areas results in a decrease in understory vegetation (Tausch and Tueller 1990). This decrease in understory vegetation increases the potential for change in ant communities as well as in other taxa and, therefore, must continue to be monitored.

Modern conservation biology upholds that variety in natural habitat features supports higher species diversity (Bestelmeyer and Wiens 2001, MacDougall et al. 2004, Oliver et al. 2004). These habitat features can be manipulated by well-designed prescribed burns (Andrew et al. 2000). Our study results may indicate that burns conducted in a patchy, heterogenous fashion can provide a variety of habitat conditions and facilitate the persistence of diversity in ant species. Maintaining variety in natural habitat features includes variety in elevations. Ant species were closely aligned with the elevation gradient in this study, and these results are supported by other studies conducted in Nevada ranges (Fleishman et. al. 1998, 2000, Sanders 2002, Sanders et. al. 2003). Therefore, we conclude that conservation management in these ecosystems should include a range of elevations to ensure maximum conservation of species diversity.

\section{ACKNOWLEDGMEnTS}

This project was facilitated by the Humbolt-Toiyabe National Forest and the BLM Battle Mountain District and funded by Joint Fire Sciences Project \#00-2-15. Thank you! Additional funding and equipment were provided by the Department of Biology, University of Nevada, Reno. We also thank the USDA Forest Service, Rocky Mountain Research Station, for field assistance and technical support. Thank you to the Yomba-Shoshone Tribe for your thoughts and ant knowledge. Much appreciation is extended to Brandon Bestlemeyer and Thomas Crist for help and insights with this project from start to finish. We are grateful to Philip Ward and Jeff Knight 
for assistance with ant identification. Thank you also to Erica Fleishman, Nathan Sanders, and 2 anonymous reviewers for commenting on the manuscript.

\section{Literature Cited}

Agosti, D., J.D. Majer, L.E. Alonso, and T.R. Schultz, EDITORS. 2000. Ants: standard methods for measuring and monitoring biodiversity. Smithsonian Institution Press, Washington, DC. $280 \mathrm{pp}$

Andersen, A.N. 1991. Responses of ground-foraging ant communities to three experimental fire regimes in a savanna forest of tropical Australia. Biotropica 23 (part B):575-585.

1997. Functional groups and patterns of organization in North American ant communities: a comparison with Australia. Journal of Biogeography 24:433460.

Andersen, A.N., B.D. Hoffmann, W.J. Müller, and A.D. GRIFFITHS. 2002. Using ants as bioindicators in land management: simplifying assessment of ant community responses. Journal of Applied Ecology 39:8-17.

Andersen, A.N., B.D. Hoffmann, and J. Somes. 2003. Ants as indicators of minesite restoration: community recovery at one of eight rehabilitation sites in central Queensland. Ecological Management and Restoration 4(s1):S12-S19.

Andersen, A.N., And J.D. Majer. 2004. Ants show the way Down Under: invertebrates as bioindicators in land management. Frontiers in Ecology and the Environment 2:291-298.

Andersen, A.N., and W.J. Müller. 2000. Arthropod responses to experimental fire regimes in an Australian tropical savannah: ordinal-level analysis. Austral Ecology 25:199-209.

Andersen, A.N., AND G.P. Sparling. 1997. Ants as indicators of restoration success: relationship with soil microbial biomass in the Australian seasonal tropics. Restoration Ecology 5:109-114.

ANDERSEN, A.N., AND A.L. YEn. 1985. Immediate effects of fire on ants in the semi-arid mallee region of north-western Victoria. Australian Journal of Ecology 10:25-30.

Andrew, N., L. Rodgerson, And A. York. 2000. Frequent fuel-reduction burning: the role of logs and associated leaf litter in the conservation of ant biodiversity. Austral Ecology 25:99-107.

Bestelmeyer, B.T., D. Agosti, L.E. Alonso, C.R.F. Brandãu, W.L. Brown, Jr., J.H.C. Delabie, and R. SilvestRe. 2000. Field techniques for the study of ground-dwelling ants: an overview, description, and evaluation. Pages 122-144 in D. Agosti, J.D. Majer, L.E. Alonso, and T.R. Schultz, editors, Ants: standard methods for measuring and monitoring biodiversity. Smithsonian Institution Press, Washington and London.

Bestelmeyer, B.T., and R.L. Schooley. 1999. The ants of southern Sonoran Desert: community structure and the role of trees. Biodiversity and Conservation 8:643-657.

Bestelmeyer, B.T., and J.A. Wiens. 1996. The effects of land use on the structure of ground-foraging ant communities in the Argentine Chaco. Ecological Applications 6:1225-1240.
2001. Ant biodiversity in semiarid landscape mosaics: the consequences of grazing vs. natural heterogeneity. Ecological Applications 11:1123-1140.

Bliss, G., L. MarZ, and S. StEenhoeck. 1999. Forest fire has no significant effect on abundance or diversity of edaphic arthropods at CERA [cited July 2003]. Tillers: A Journal of Prairie Restoration Research 1:[no pagination]. Available from: http://www.grinnell.edu/academic/biology/cera/research/tillers/.

Chambers, J.C., R.J. Tausch, M.C. Amacher, D. GerManoski, E. Fleishman, and D. Zamudio. 2000. A demonstration area on ecosystem response to watershed-scale burns in Great Basin pinyon-juniper woodlands. USDA Forest Service, Proposal to the Joint Fire Science Program RFP 2000-2, Rocky Mountain Research Station, Reno, NV.

Crist, T.O., AND J.A. MaCMahON. 1991. Foraging patterns of Pogonomyrmex occidentalis (Hymenoptera: Formicidae) in a shrub-steppe ecosystem: the roles of temperature, trunk trails, and seed resources. Environmental Entomology 20:265-275.

1992. Harvester ant foraging and shrub-steppe seeds: interactions of seed resources and seed use. Ecology 73:1768-1779.

Davidson, D.W., R.S. Inouye, and J.H. Brown. 1984. Granivory in a desert ecosystem: experimental evidence for indirect facilitation of ants by rodents. Ecology 65:1780-1786.

Davidson, D.W., D.A. SAMSOn, and R.S. InOuYe. 1985. Granivory in the Chihuahuan Desert: interactions within and between trophic levels. Ecology 66:486502.

Farji-Brener, A.G., J.C. Corley, and J. Bettinelli. 2002. The effects of fire on ant communities in north-western Patagonia: the importance of habitat structure and regional context. Diversity and Distributions 8: $235-243$.

Fleishman, E., G.T. Austin, and A.D. Weiss. 1998. An empirical test of Rapoport's rule: elevational gradients in montane butterfly communities. Ecology 79:24822493.

Fleishman, E., J.P. FaY, and D.D. MuRPhy. 2000. Upsides and downsides: contrasting topographic gradients in species richness and associated scenarios for climate change. Journal of Biogeography 27:1209-1219.

Golden, D.M., AND T.O. CRIST. 2000. Experimental effects of habitat fragmentation on rove beetles and ants: patch area or edge? Oikos 90:525-538.

Hölldobler, B., AND E.O. WiLson. 1990. The ants. Belknap Press of Harvard University Press, Cambridge, MA. 732 pp.

KaUfFman, J.B. 2004. Death rides the forest: perceptions of fire, land use, and ecological restoration of western forests. Conservation Biology 18:878-882.

Littell, R.C., G.A. Milliken, W.W. Stroup, R.D. WolfinGER, AND O. SCHABENBERGER. 2006. SAS for mixed models. 2nd edition. SAS Institute, Inc., Cary, NC. $813 \mathrm{pp}$.

MacDougall, A.S., B.R. Beckwith, and C.Y. Maslovat. 2004. Defining conservation strategies with historical perspectives: a case study from a degraded oak grassland ecosystem. Conservation Biology 18:455465 .

MaEto, K., AND S. Sato. 2004. Impacts of forestry on ant species richness and composition in warm-temperate forests of Japan. Forest Ecology and Management 187(2-3):213-223. 
Majer, J.D. 1997. The use of pitfall traps for sampling ants - a critique. Memoirs of the Museum of Victoria 56(2):323-329

McCune, B., And M.J. Mefford. 1999. PC-ORD. Multivariate analysis of ecological data. Version 4. MjM Software Design, Gleneden Beach, OR. 237 pp.

McIver, J.D., AND K. YandelL. 1998. Honeydew harvest in the western thatching ant (Hymenoptera: Formicidae). American Entomologist 44:30-35.

Miller, R.F., AND J.A. Rose. 1999. Fire history and western juniper encroachment in sagebrush steppe. Journal of Range Management 52:550-559.

Miller, R.F., T.J. SvejCaR, AND J.A. Rose. 2000. Impacts of western juniper on plant community composition and structure. Journal of Range Management 53:574585.

Miller, R.F., and R.J. Tausch. 2001. The role of fire in pinyon and juniper woodlands: a descriptive analysis. Pages 15-30 in K.E.M. Galley and T.P. Wilson, editors, Proceedings of the invasive species workshop: the role of fire in the control and spread of invasive species: Fire Conference 2000: The First National Congress on Fire Ecology, Prevention, and Management (27 Nov.-1 Dec. 2000). Tall Timbers Research Station, Miscellaneous Publication No. 11, San Diego, CA.

Mull, J.F., AND J.A. MACMAhon. 1997. Spatial variation in rates of seed removal by harvester ants (Pogonomyrmex occidentalis) in a shrub-steppe ecosystem. American Midland Naturalist 138:1-13.

Oliver, I., A. Holmes, M.J. Dangerfield, M. Gillings, A.J. Pik, D.R. Britton, M. Holley, ET AL. 2004. Land systems as surrogates for biodiversity in conservation planning. Ecological Applications 14:485-503.

Punttila, P., Y. Haila, J. Niemelä, and T. Pajunen. 1994. Ant communities in fragments of old-growth taiga and managed surroundings. Annales Zoological Fennici 31:131-144.

Punttila, P., Y. Haila, and H. Tukia. 1996. Ant communities in taiga clearcuts: habitat effects and species interactions. Ecography 19:16-28.

Ratchford, J.S., S.E. Wittman, E.S. Jules, A.M. ElliSON, N.J. Gotelli, and N.J. Sanders. 2005. The effects of fire, local environment and time on ant assemblages in fens and forests. Diversity and Distributions 11:487-497.

Rau, B.M., J.C. Chambers, R.R. Blank, and W.W. Williams. 2005. Hydrologic response of a central Nevada pinyon-juniper woodland to prescribed fire. Rangeland Ecology and Management 58:614-622.

Read, J.L., And A.N. Andersen. 2000. The value of ants as early warning bioindicators: responses to pulsed cattle grazing at an Australian arid zone locality. Journal of Arid Environments 45:231-251.

Reiner, A.L. 2004. Fuel load and understory community changes associated with varying elevation and pinyonjuniper dominance. Master's thesis, University of Nevada, Reno.

SANDERS, N.J. 2002. Elevational gradients in ant species richness: area, geometry, and Rapoport's rule. Ecography $25: 25-32$.
Sanders, N.J., J. Moss, and D. Wagner. 2003. Patterns of ant species richness along elevational gradients in an arid ecosystem. Global Ecology and Biogeography 12:93-102.

Swetnam, T.W. 1993. Fire history and climate change in giant sequoia groves. Science 262:885-889.

Tausch, R.J., C.L. NowaK, And S.A. Mensing. 2004. Climate change and associated vegetation dynamics during the Holocene: the paleoecological record. Pages 24-48 in J.C. Chambers and J.R. Miller, editors, Great Basin riparian ecosystems: ecology, management, and restoration. Island Press, Washington, DC.

Tausch, R.J., and P.T. Tueller. 1990. Foliage biomass and cover relationships between tree- and shrubdominated communities in pinyon-juniper woodlands. Great Basin Naturalist 50:121-134.

Tausch, R.J., N.E. West, and A.A. NABI. 1981. Tree age and dominance patterns in Great Basin pinyonjuniper woodlands. Journal of Range Management 34:259-264.

Weixelman, D.A., D.C. Zamudio, and K.A. Zamudio. 1996. Central Nevada riparian field guide. USDA Forest Service, Intermountain Region, Ogden, UT.

Wheeler, G.C., AND J.N. WheEler. 1986. The ants of Nevada. Natural History Museum of Los Angeles County, Los Angeles, CA.

Whitford, W.G., J. Van Zee, M.S. Nash, W.E. Smith, AND J.E. HERRICK. 1999. Ants as indicators of exposure to environmental stressors in North American desert grasslands. Environmental Monitoring and Assessment 54:143-171.

Wilson, E.O. 2000. Forward. Pages xv-xvi in D. Agosti, J.D. Majer, L.E. Alonso, and T.R. Schultz, editors, Ants: standard methods for measuring and monitoring biodiversity. Smithsonian Institution Press, Washington, DC.

Wisdom, M.J., M.M. Rowland, B.C. Wales, M.A. Hemstrom, W.J. Hann, M.G. Raphael, R.S. Holthausen, ET AL. 2002. Modeled effects of sagebrush-steppe restoration on Greater Sage-Grouse in the interior Columbia Basin, USA. Conservation Biology 16:12231231.

York, A. 1994. The long-term effects of fire on forest ant communities: management implications for the conservation of biodiversity. Memoirs of the Queensland Museum 36:231-239.

2000. Long-term effects of frequent low-intensity burning on ant communities in coastal blackbutt forests of southeastern Australia. Austral Ecology 25: 83-98.

Zimmer, K., And R.R. PARmenter. 1998. Harvester ants and fire in a desert grassland: ecological responses of Pogonomyrmex rugosus (Hymenoptera: Formicidae) to experimental wildfires in central New Mexico. Population Ecology 27:282-287.

Received 7 July 2006 Accepted 5 February 2007 


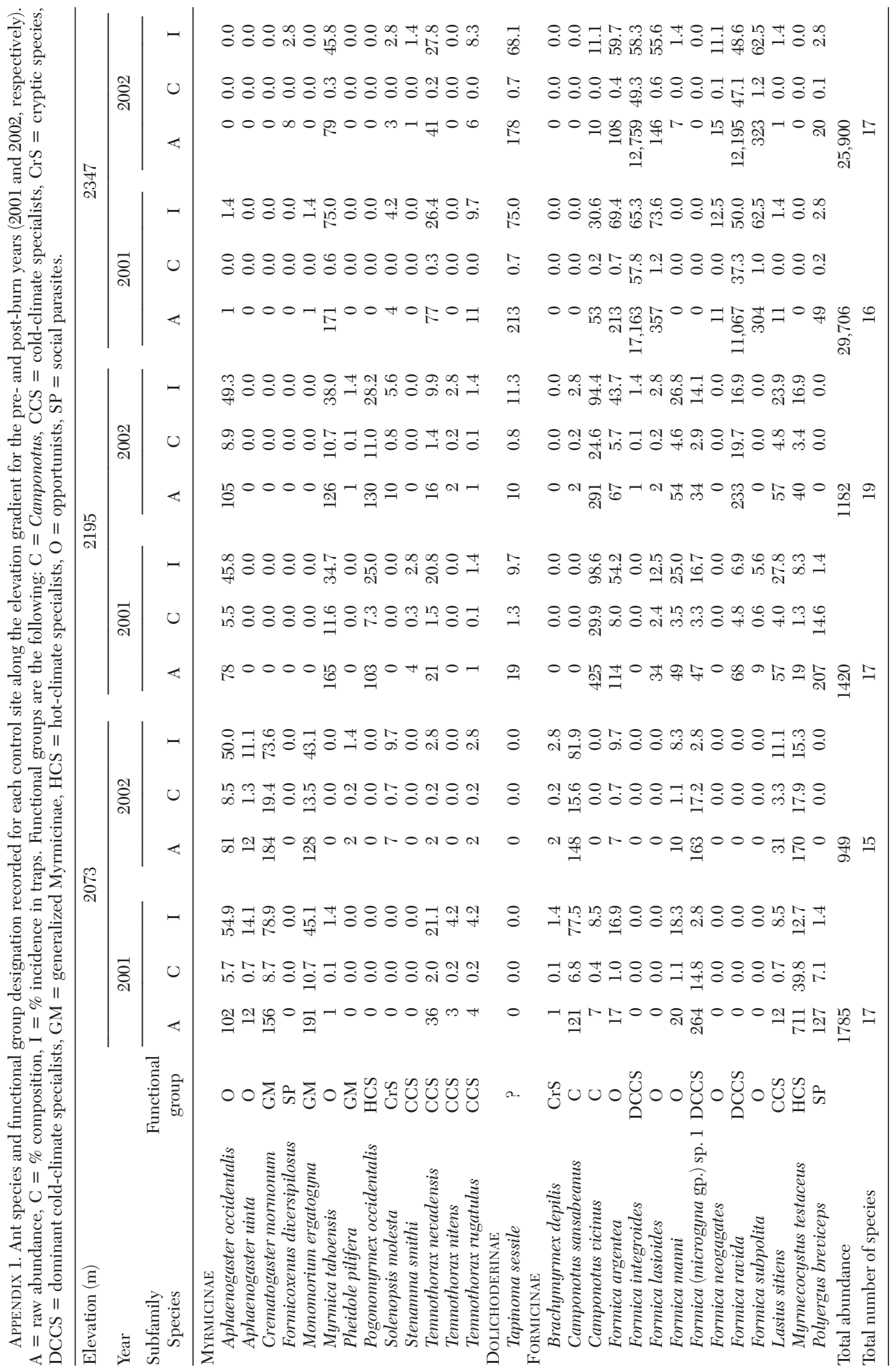




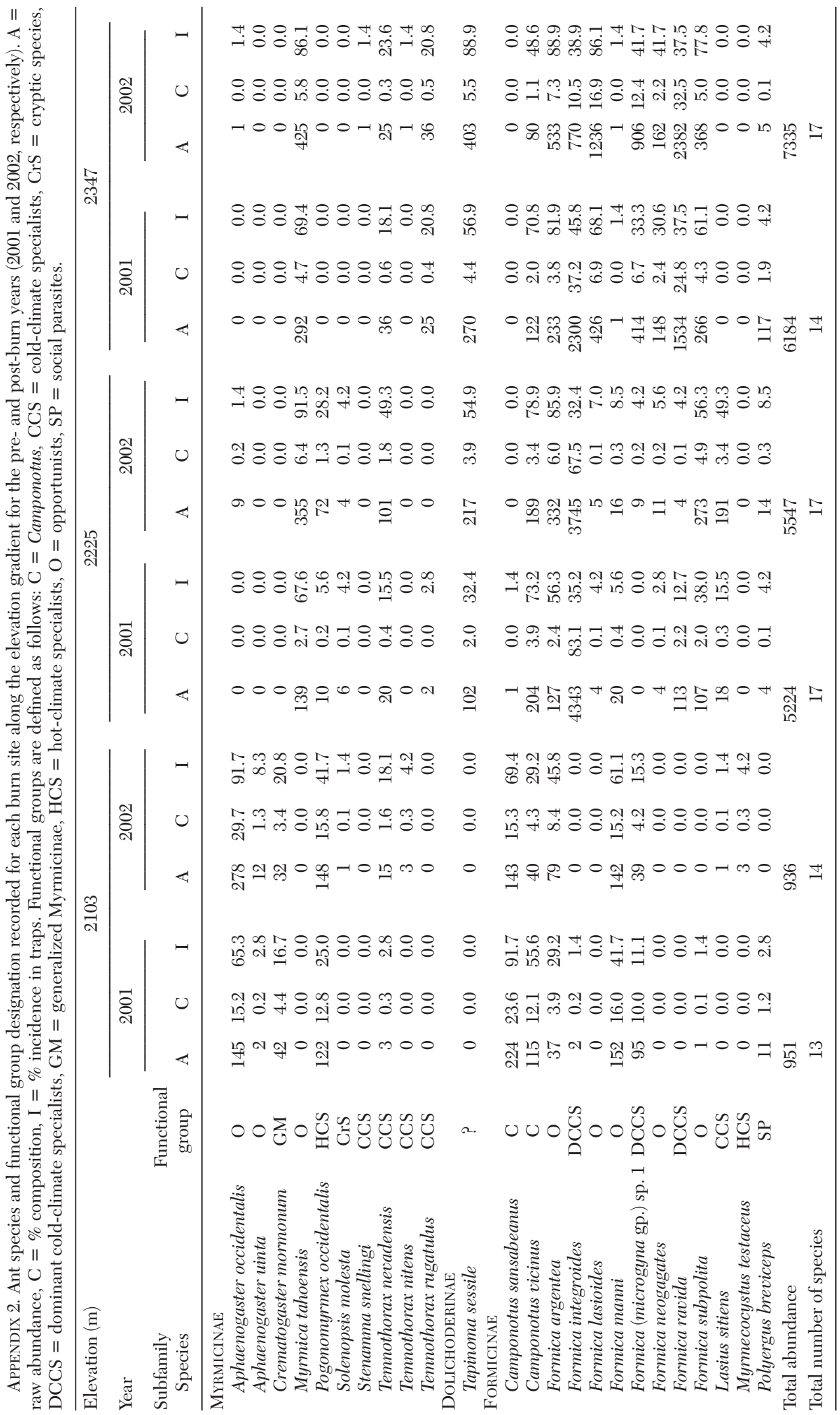




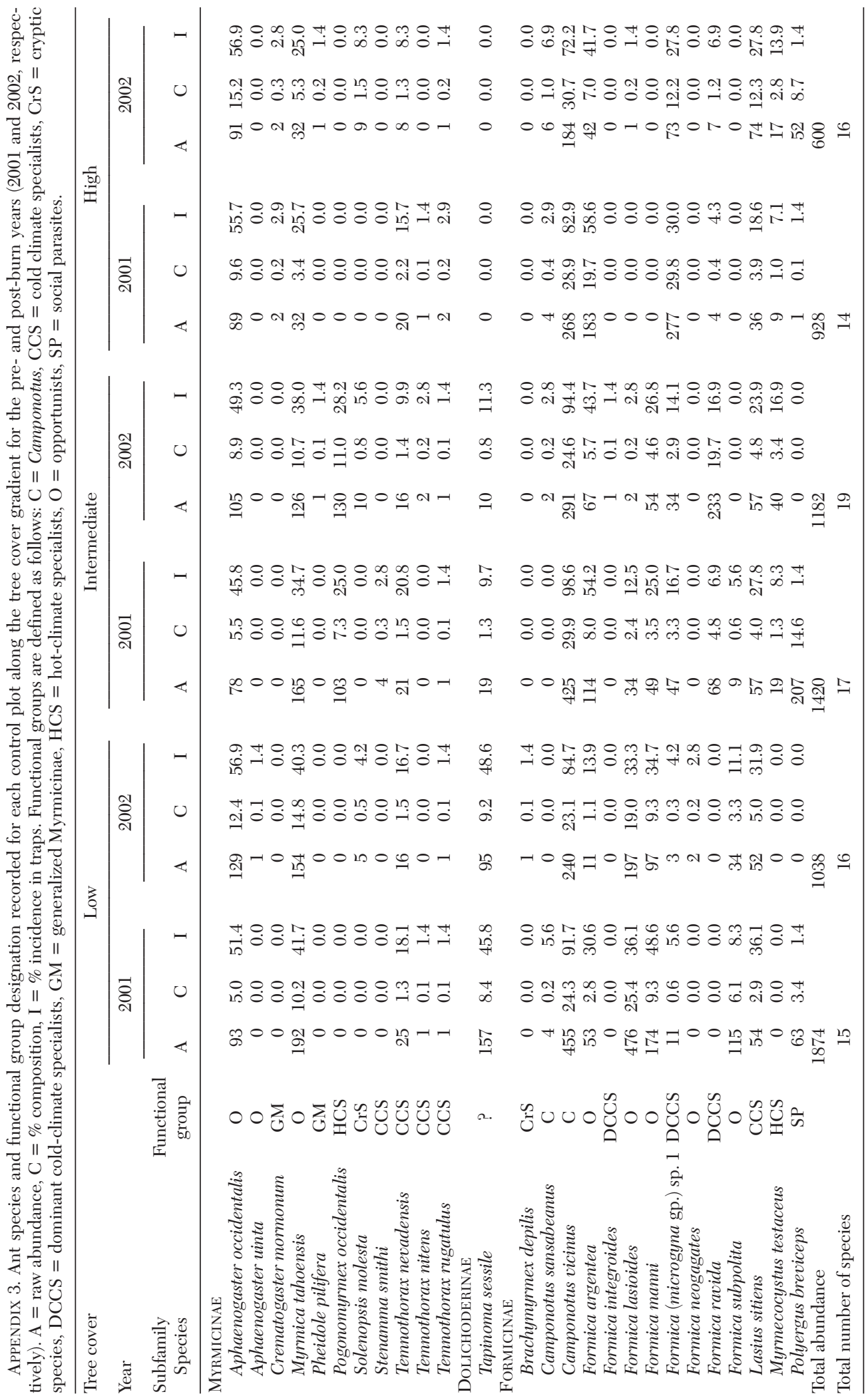




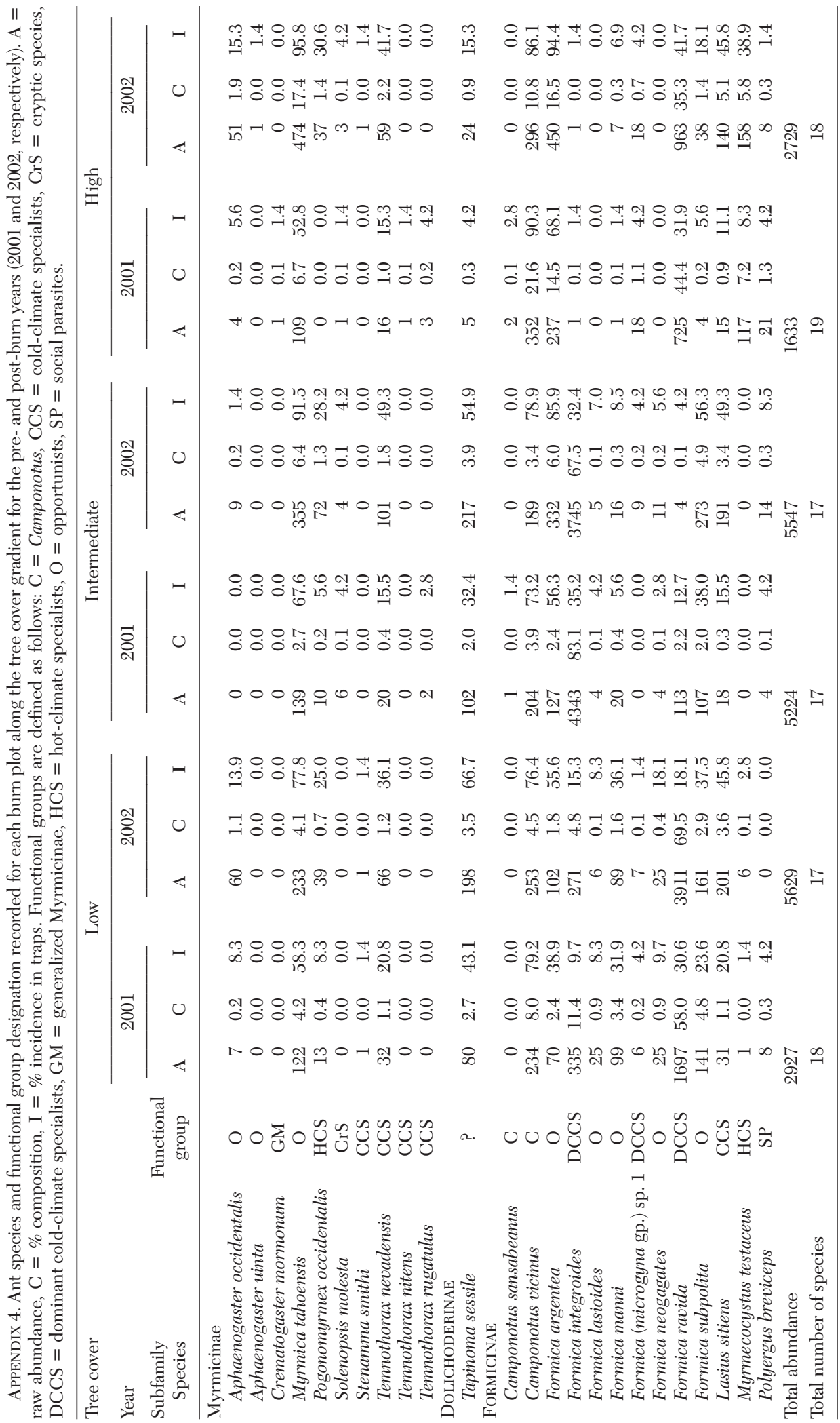

